\title{
International Migration As A Driver Of Country Development
}

https://doi.org/10.21272/sec.5(1).133-143.2021

\section{Denys Pudryk}

The Customer Service in Odessa, Ukraine

\begin{abstract}
The expression of the country's sustainable socio-political development is its achievement of macroeconomic stability, which, first of all, depends on the ability of the national economy to ensure the growth of macroeconomic indicators. It raises many questions about identifying and evaluating factors that directly and indirectly impact growth. In recent decades, more and more attention is paid to the problems of developed countries' human capital security and their importance for macroeconomic processes. Human resources can be interpreted as explicit (labor resources) and implicit (ethnic, age, language, qualification distribution, etc.) factor influencing macroeconomic indicators. Since most economically advanced states belong to the category of old nations, they have faced another global problem in the last half-century - the population's rapid ageing. Their gradual degeneration leads to the inhibition of positive macroeconomic processes. Therefore there is a need to attract new human resources, and migration is one of the most effective levers to solve this problem. However, migration can pose several threats to both the destination country and the donor country. In the economic context for the destination country, the most serious of these is the lack of the desired improvement in human potential due to the influx of low-skilled workers. In contrast, for the country of origin, there is a brain drain. It creates the problem of determining the factors that affect population migration between the donor country and the destination country, and their correlation with macroeconomic indicators. The purpose of this work is to conduct a generalized analysis of methodologies for assessing the interconnectedness of macroeconomic and migration determinants and identifying commonalities. According to the work results, it was found that most of the analyzed scientists use simple estimation models, filling them with related indirect migration factors and macroeconomic indicators, which are formed depending on the primary goal of the work. Thus, this study allows us to create a list of migration determinants commonly used in typical results, to form an updated methodological framework.
\end{abstract}

Keywords: population, migration, macroeconomic stability, gravitational model.

JEL Classification: O15, J61.

Cite as: Denys Pudryk (2021). International Migration As A Driver Of Country Development. SocioEconomic Challenges, 5(1), 133-143. https://doi.org/10.21272/sec.5(1).133-143.2021.

Received: 02.02 .2021

Accepted: 7.03.2021

Published: 30.03 .2021

Copyright: (C) 2021 by the author. Licensee Sumy State University, Ukraine. This article is an open access article distributed under the terms and conditions of the Creative Commons Attribution (CC BY) license (https:// creativecommons.org/licenses/by/4.0/).

\section{Introduction}

Ensuring stable growth of the national economy is possible provided that macroeconomic stability is achieved, the formation of which depends on many macroeconomic indicators. However, forecasting the development of these elements today is impossible solely by considering financial and economic factors. Thus, in the context of globalization and geopolitical uncertainty et al.levels, there is a need to determine the impact of implicit factors.

The most influential implicit factors include the country's human capital. It is crucial for many economic indicators that ensure the economy's functioning at both micro and macro levels. It is because sufficient human capital provides the national labour market's needs, opportunities for the development of the country's intellectual 
potential, and address several socio-economic needs. But no country has an ideal human resource, so we need to move between them. This movement is provided by migration.

According to the definition given by the International Organization for Migration (IOM) (Key Migration Terms, 2020) "Migration is the movement of persons away from their place of usual residence, either across an international border or within a State". Yet migration is a much more complex process than simply moving a person from one place to another. Many socio-cultural and economic factors influence it. Yes, most people migrate to improve their well-being, get a better education, better living conditions and medicine, fleeing political and ethnic-religious persecution. However, it should be noted that migration processes are a bilateral phenomenon, and the destination country can act as a donor country. It can be clearly seen in the example of the map of international migration for the period 2010-2015 (Figure 1) (All the World's Immigration Visualized in 1 Map, 2016).

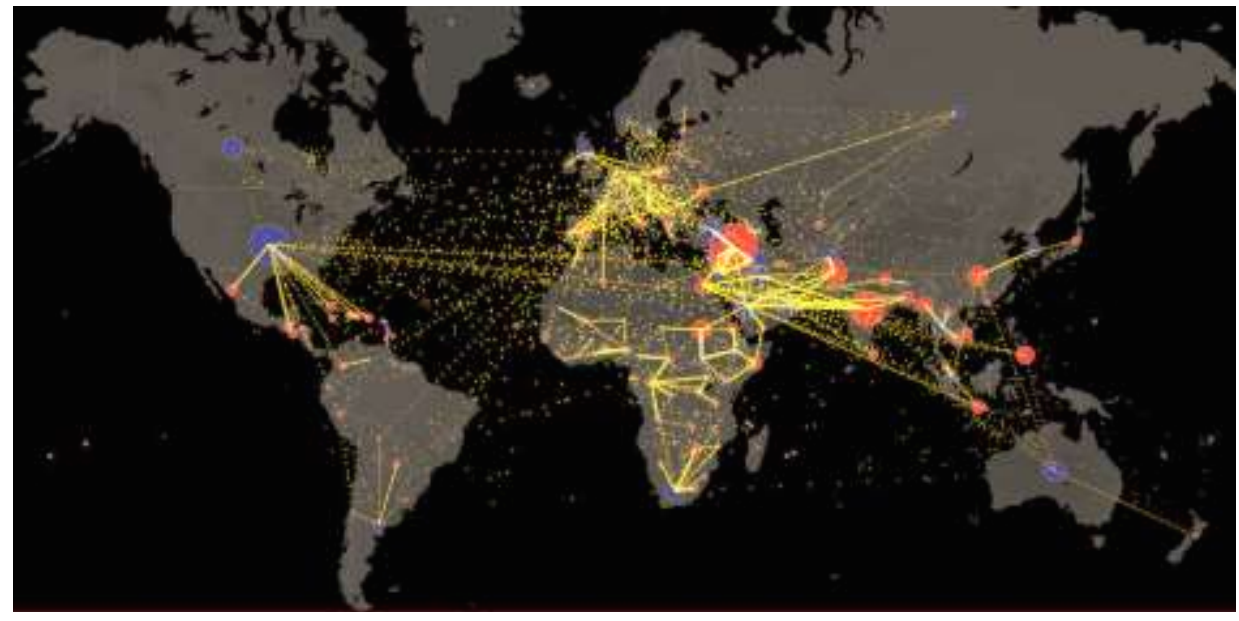

Figure 1. World Migration Map

Source: All the World's Immigration Visualized in 1 Map. (2016).

Let's analyze the statistics of the U.N. Population Division (International migrant stock 2019, 2019) and The 2019 edition of International Migration and Displacement Trends and Policies Report to the G20 (2019). Almost the majority of all migrants are from the G20. On the European continent, according to the official website (G20 Participants, 2020), the G20 includes France, Germany, Italy, Russia, the United Kingdom, the European Union (EU). It indicates the study of the impact of migration processes on European countries' macroeconomic indicators.

Another essential factor that identifies Europe as a priority subject of research is the rather complex demographic situation. Most experts point to an increase in the average age of the old nations. This factor's importance is emphasized in The 2019 edition of International Migration and Displacement Trends and Policies Report to the G20 (2019). Thus, the paper states that the average G20 nation has aged ten years over the past forty years.

Data analysis U.N. Population Division (International migrant stock 2019, 2019) on the population in European countries, on the one hand, indicates population growth in countries such as Great Britain and France, and on the other reduction - Bulgaria, Poland, Romania, Ukraine (Figure 2). Accordingly, there is a need to identify marker(s) that can explain these processes. 


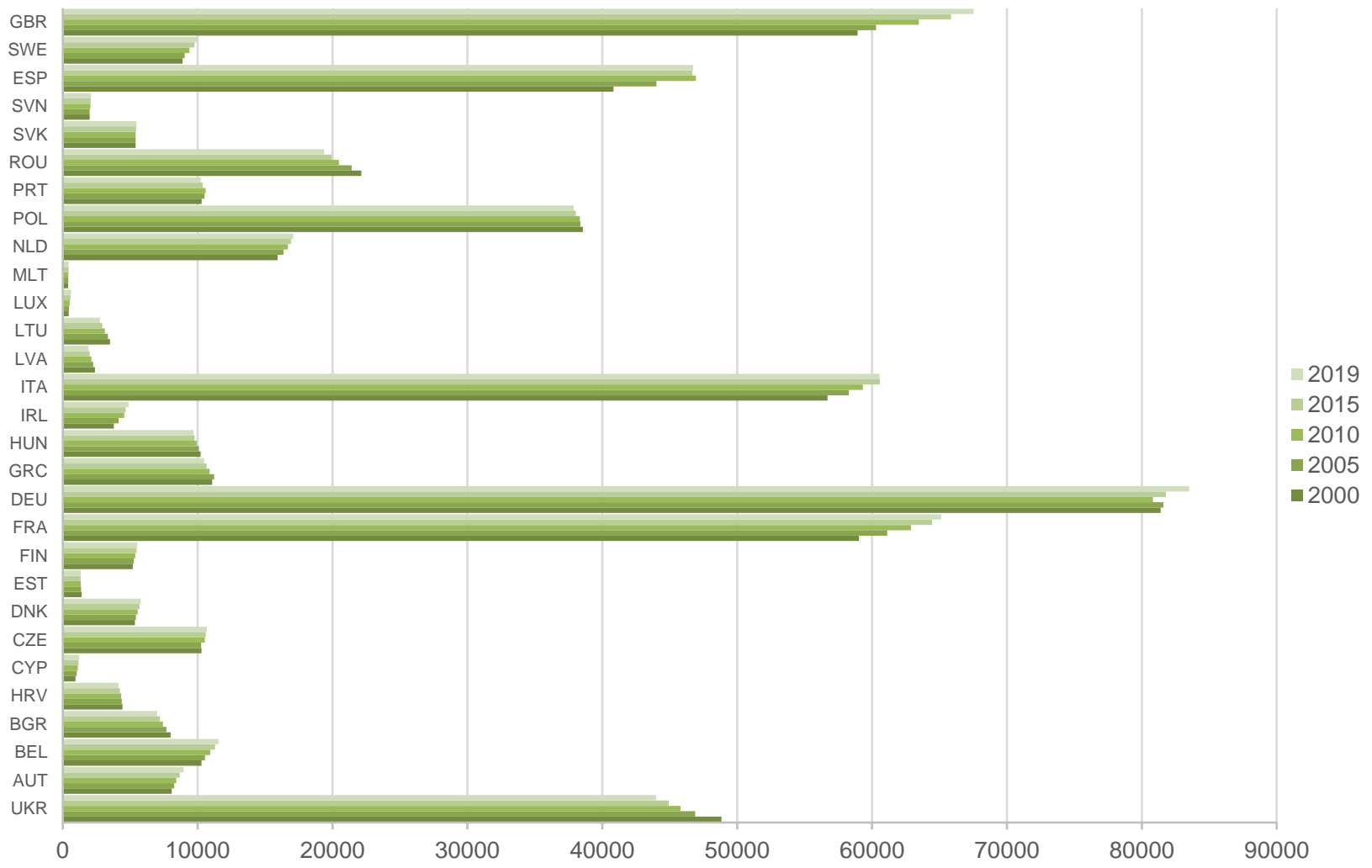

Figure 2. Dynamics of population change in 2000-2018, thousand population

Source: built on U.N. Population Division (International migrant stock 2019, 2019).

According to the results of the analysis of data presented in the Database Eurostat (2019) on the ratio of births and deaths in European countries, we observe negative dynamics (Figure 3). This trend confirms the thesis of the ageing of the nation. However, some of the studied countries stand out from the general direction. A clear example is the United Kingdom, where the population has grown by almost eight million in eighteen years, with a difference between births and deaths of just over three million.

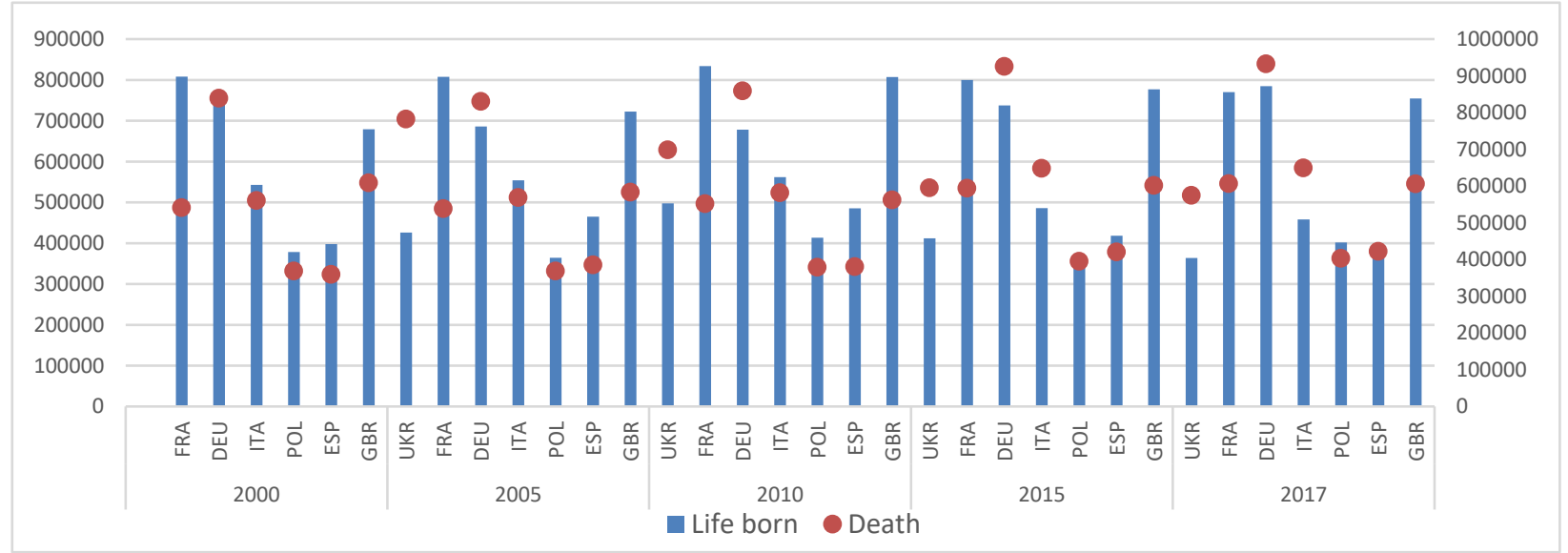

Figure 3. Dynamics of births and deaths of the population in 2000-2017.

Note: data from Ukraine, France, Germany, Italy, Poland, Spain, Great Britain are given. Data for Ukraine for 2000 are missing. Source: based on Eurostat Database (2019). 
However, some of the studied countries stand out from the general trend. A clear example is the United Kingdom, where the population has grown by almost eight million in eighteen years, with a difference between births and deaths of just over three million. Thus, such markers as birth rate and mortality do not reflect the actual state of the demographic situation, reflecting the importance of considering migration processes in assessing their impact on socio-economic aspects of life.

\section{Literature Review}

According to the International Migrant Stock 2019 (2019) analysis, 3.5\% of the world's population lives outside their country of origin, of which $7.51 \%$ are refugees. Such growth leads to significant changes in the country's economic and political life. Therefore, António Vitorino's words in the preface to World Migration Report 2020 (2019) that migration is one of the crucial issues today are pretty reasonable.

John Lewis and Matt Swannell (2018) analyze macroeconomic factors influencing migration processes. Their study is based on applying a gravitational model (reflecting the estimate of flow volumes between two or more points), which has many determinants and is designed to study pairwise data of 160 countries of origin of migrants and 35 countries with developed economies. The authors (John Lewis and Matt Swannell, 2018) identify the following determinants:

Demographic - based on legal migration data provided by Adserà and Pytliková (2015), OECD's International Migration Database OECD (2017) and Özden et al. (2011);

$>\quad$ Macroeconomic - GDP per capita, population, unemployment rate and real exchange rate;

$>\quad$ Linguistic - considers the impact of language barriers between the destination country and the donor country.

$>$ Geographical, historical and other - based on the historical and geographical kinship between the destination country and the donor country, as well as the protection of employment and the number of short-term contracts in total;

$>\quad$ Freedom of movement - based on the impact of agreements between countries/groups of the country on the free movement of population.

Thus, John Lewis and Matt Swannell note that most of their proposed indicators impact migration between countries. For example, a 1\% increase in the donor country's GDP reduces the expected migration by $1.7 \%$. Yes, no less important is the trend that linguistic and historical (especially in terms of colonial ties) affinity have a positive effect on the number of migrants between such countries; a significant share is also present in the determinants of "freedom of movement".

Melitz J. and Toubal F. (2014) investigated the impact of language on trade relations, including in the context of migration, using the determinants of affinity and knowledge of at least one of the two languages used by migrants indigenous peoples. Using a gravitational model to assess the impact of variables, the authors concluded that the role of migrants in building confidence in goods is positive because it simplifies linguistic barriers and costs. Thus, studies by Melitz J. and Toubal F. and John Lewis and Matt Swannell emphasize the importance of taking into account language variables.

Scientific alliances of domestic and foreign scientists Kharazishvili Y. et al.(2020), Rui L. et al.(2019), Korobets O. et al. (2018), Pimonenko T., (2017) study the level of social security of society, taking into account the main economic, financial and institutional determinants. Scientists use modern methods of normalization, the threshold vector of determination and dynamic weights to identify society's level of social security.

Campos and Timini (2019) and Berthou A. et al. (2019) study the impact of Brexit on macroeconomic stability and migration. Their work differs significantly in the structure of the chosen model for the assessment of impact factors. Thus, the former uses a gravity model, while the latter - NiGEM (National Institute Global Econometric Model) (The model, 2020) - a global macroeconomic model that considers indicators from more than 60 countries and regions to form economic scenarios and models. As a result, Campos and Timini estimate that the impact of Brexit will reduce UK migration flows by a quarter, while for the rest of the community, the increase will be $2 \%$. Berthou A. et al. interpret migration losses in macroeconomic terms due to a different assessment methodology. 
Thus, as a result of Brexit, the expected GDP decline will be $0.4 \%$ for the UK, for the rest of the countries will grow by $0.3 \%$.

Analysis of research by Bilan Y. et al.(2020), Rosokhata A. et al.(2020), Rosokhata A. (2014), Panchenko V. et al.(2020) allowed us to conduct a comparative analysis of indicators of the impact of migration processes between donor countries and recipient countries, taking into account economic and innovative determinants. It is also necessary to note the scientific works of Chygryn O. (2016), Chygryn O., et al. (2011), Ziabina Ye., et al. (2020), which revealed current issues regarding the effectiveness of the implementation of environmentally friendly measures, as well as analysis of social, environmental and economic determinants on the level of energy efficiency of the national economy, which in the complex makes it possible to determine the diversity of drivers of the country's development.

Changyao Song et al. (2019) conducted a study of the impact of emigration processes on outward foreign direct investment (OFDI) in the tourism segment. The work is based on negative binomial models. To evaluate the data, the authors use OFDI in tourism, the logarithm of the emigration potential, an additional formula that includes control variables (invest, outbound, touraco), and error. As a result, it was determined that emigration has a significant impact on OFDI in tourism: an increase in emigration by $1 \%$ leads to an increase in OFDI by 3.23 times, but in the long run - by 2.41 .

Bozhkova V.V. et al. (2018), Letunovska N. et al. (2021), Pimonenko T. et al. (2017) examine the processes of globalization and the effectiveness of government regulation in the context of the development of environmental management and social marketing. The presented studies use bibliometric analysis, most miniature squares models and correlation analysis.

It is advisable to pay attention to the works of Pimonenko T., Lushchik, K.V. (2017), Pimonenko T., Lyulyov O. (2019), Pimonenko T. et al. (2018), Pimonenko T. et al. (2017), in which research on the effectiveness of green investment development and the feasibility of implementing marketing tools to increase environmental competitiveness both at the enterprise level and at the macroeconomic level.

Tong S.Y. (2005) studies the importance of ethnic networks in foreign direct investment (FDI). The assessment uses a gravitational model that analyzes the impact of determinants such as FDI, GNP, population of origin and destination, DIST, distance between countries, land border, whether a country is a member of the European Community and the European Free Trade Association, linguistic and historical ties, the tariff rate of the country of destination, the average ratio between trade and GDP, the number of ethnic groups of the country of origin. As a result of the study, the author finds that the state of economic development has a significant impact on FDI; the higher it is and the higher the share of foreign direct investment. Non-economic factors such as geographical distance between countries, common historical space, especially colonial ties, common language and membership of the European Union are also important.

Therefore, summarizing the above studies, we can identify the following trends:

1) Among the assessment of the impact of migration determinants are the most common standard models for assessing their impact, such as the gravitational model.

2) Most studies related to assessing the impact of migration processes on macroeconomic indicators use identical groups of determinants (demographic, historical, linguistic, etc.).

3) Most researchers conclude that historical and linguistic determinants play a significant role in a migrant's destination choice.

4) Taking into account such a determinant as "freedom of movement" allows a more effective assessment of migration motives.

5) Most scientists have proven the impact of migration processes on the macroeconomic situation. However, it is essential to emphasize that the degree of their significance strongly correlates with the chosen valuation model and the macroeconomic indicator itself, which is the object of study. 


\section{Methodology}

To verify the long-term two-way relationship between the flow of migration and indicators of economic, social, environmental, political levels of development in the first stage, a bibliometric analysis based on VOSviewer, and the second carried out econometric modeling of selected indicators (Mig - migration level), calculated according to the World Bank (2020), indicators of economic development - GDP per capita (GDP), GNI per capita (GNI)), social - Unemployment (Un), Gross Average Monthly Wages by Indicator, Country and Year (Wag)), ecological - Renewable energy consumption (RE)) using the Fully Modified OLS (FMOLS) and Dynamic OLS (DOLS) panel cointegration techniques:

$$
y_{i, t}=a_{i}+\sum_{i=1}^{K} \lambda_{i}^{(k)} y_{i, t-k}+\sum_{i=1}^{K} \beta_{i}^{(k)} x_{i, t-k}+\varepsilon_{i, t}
$$

where $\beta_{i}^{(k)}, a_{i}, \lambda_{i}^{(k)}, \beta_{i}^{(k)}$ - indicate constant term, lag parameter and coefficient slope, $y_{i, t}, x_{i, t}-$ time data.

\section{Results}

During the period 2000-2019, the number of publications on international migration had an eastern trend. In particular, according to the Scopus database dedicated to the topic in the study period, 6930 research documents were published (Fig. 4a). The most significant percentage $81.0 \%$ have articles, $6.7 \%$ - review, 6.2\% - book chapter. The average annual growth rate of publications is $120 \%$, so the average number of publications per year increases by $20 \%$. The largest share of publications falls on the EU countries (United Kingdom - 980 publications, France - 324, Italy - 348, Germany - 424, Spain - 335, Netherlands - 290). It indicates that international migration issues are widely studied in European countries, demonstrating the dynamic development of this industry. (Fig. 4 b).

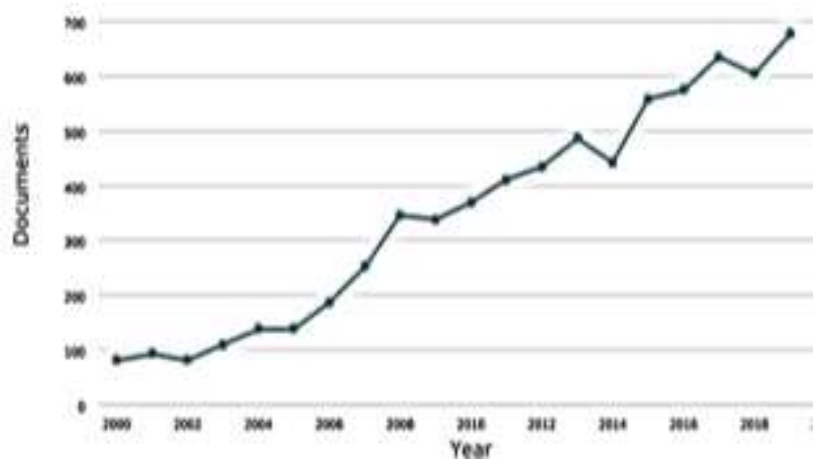

a) Documents by year

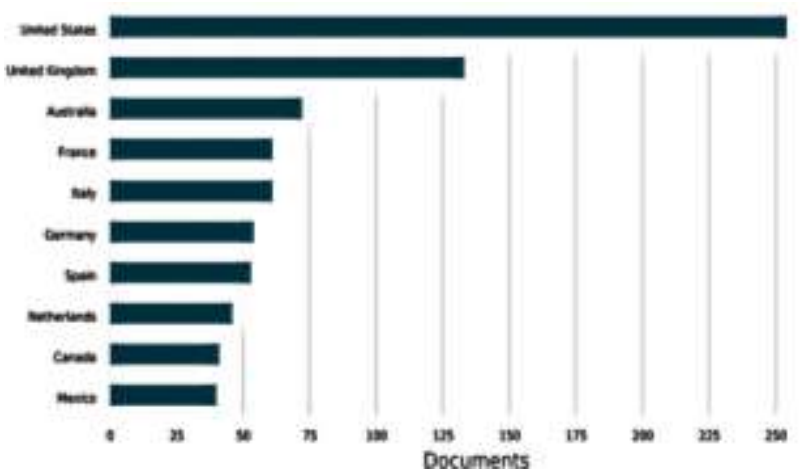

b) Documents by country or territory

Figure 4. Dynamics (a) and country of origin (b) of publications on international migration 2000-2019

Source: built based on the Scopus database (2020).

A large number of articles on international migration has previously been published by Hugo G. (25), King R. (17), Massey D.S. (16), Docquier F. (15), Strielkowski W. (15). In particular, most of Hugo G.'s work is devoted to studying the impact of migration processes on the development of various spheres of life in Australia. In the publication (Tan \& Hugo, 2017), researchers study the effects of education in Australia on Chinese and Indian students' migration processes to this country. The authors emphasize the positive effects of lifelong mobility on students and the growth of a highly skilled workforce in Australia. Transnational migration strategies of international students to overcome barriers to migration policy. Sondhi G. and King R. (2017) study the gender aspects of international student migration. Durand J. and Massey D. S. (2019), in their work, emphasize the inconsistency of the migration policy of the destination country and the realities of immigration. Then, as Docquier F. at all. (2017) examines the impact of bilateral migration on the causes of military conflicts between nations. Strielkowski W. and other scientists in work et al., 2018) study population outflow effects on countries' macroeconomic stability. The basis was a regression model, which identified such determinants as current account 
balances, FDI, migrant remittances, minimum wage, time variable and error. The results obtained by scientists indicate a statistically significant dependence on the studied countries' macroeconomic indicators and remittances of migrants. The authors also note the critical role of the country's minimum wage to decide the population to emigrate to another country.

Analyzing the titles, keywords and annotations of publications using the Scopus database using the VOSviewer tool, it is evident that the literature on international migration focuses on a limited variety of topics that can be combined into four main thematic streams: (a) definitions and trends, (b) environment and living conditions, (c) management policies and (d) determinants of efficiency (Figure 5). Articles on the definition, typology, conceptualization, and description of international migration phenomena still form the dominant cluster. Instead, research should be based not only on existing definitions and conceptualizations but also on other groups' giving more weight by further diversifying international migration research. Thus, John Lewis and Matt Swannell (2018) analyze macroeconomic factors influencing migration processes. Their study is based on applying a gravitational model (reflecting the estimate of flow volumes between two or more points), which has several determinants and is designed to study pairwise data of 160 countries of origin of migrants and 35 countries with developed economies. The authors determine the significant impact of the selected determinants on migration processes between countries, in particular: macroeconomic - GDP per capita, population, unemployment rate and real exchange rate; geographical, historical and other - based on the historical and geographical kinship between the destination country and the donor country, as well as employment; freedom of movement - based on the impact of agreements between countries/groups of the country on the free movement of population between them.

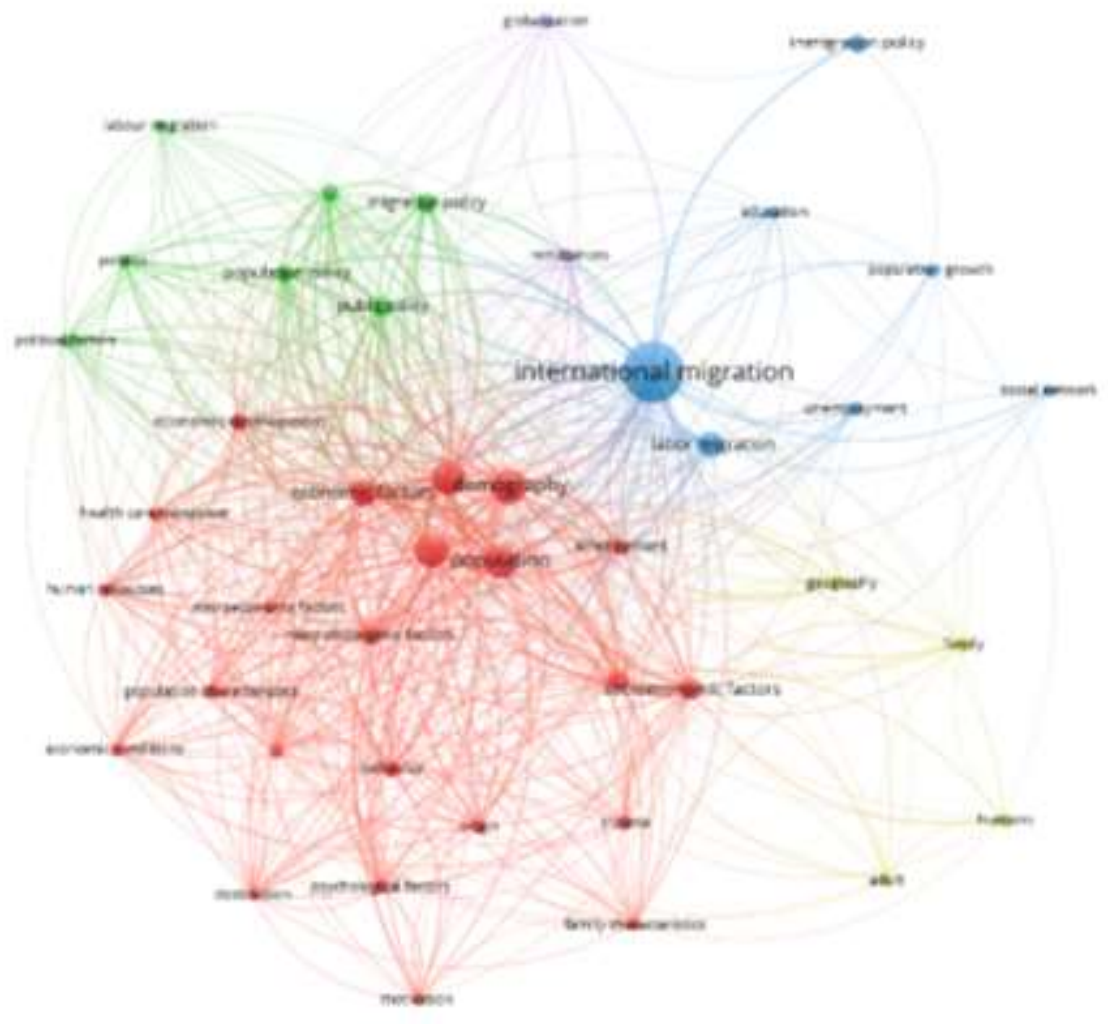

Figure 5. Content analysis of the literature on international migration and visualization by VOSviewer

Source: compiled by authors.

Table 1 presents the main descriptive characteristics (mean value, standard deviation, and the different variable's coefficient) of the model's studied parameters (2). The annual dataset for two groups of countries was obtained for two groups of countries from the World Data Bank from 2000 to 2018. 
Table 1. Descriptive statistics for Mig, GDP, GNI, UN, Wages, CC, RE, PS

\begin{tabular}{|l|c|c|c|c|c|}
\hline \multicolumn{1}{|c|}{ Variables } & Mean & Std. Dev. & CV & Min & Max \\
\hline Mig & 3591.841 & 38619.43 & 10.75199 & -165941 & 181634 \\
\hline GDP & 2942.808 & 2034.009 & 0.69118 & 354 & 8318.51 \\
\hline GNI & 2844.035 & 1926.607 & 0.67742 & 380 & 7600 \\
\hline UN & 7.334211 & 2.092743 & 0.28534 & 3.41 & 11.94 \\
\hline Wages & 259.5111 & 157.6029 & 0.607307 & 32.8 & 658.09 \\
\hline CC & -.7554386 & .2161107 & 0.28607 & -1.13 & -.19 \\
\hline RE & 5.860877 & 3.375649 & 0.575963 & .97 & 14.27 \\
\hline PS & -.2389474 & .5982853 & 2.50384 & -2.02 & .69 \\
\hline
\end{tabular}

Source: compiled by authors.

The results of using FMOLS are presented in table 2.

Table 2. Estimation of the cointegrating relationship.

\begin{tabular}{|c|c|c|c|c|}
\hline \multirow{2}{*}{ Independent Variables } & \multicolumn{2}{|c|}{ FMOLS } & \multicolumn{2}{c|}{ DOLS } \\
\cline { 2 - 5 } & Long-run coefficient & Prob & Long-run coefficient & Prob \\
\hline GDP & 1.839 & 0.191 & 5.596 & $(0.019)^{* *}$ \\
\hline GNI & -2.84 & $(0.039)^{* *}$ & -3.899 & $0.000)^{*}$ \\
\hline UN & 1.780 & 0.703 & 4.882 & 0.939 \\
\hline Wages & 18.5 & $(0.023)^{* *}$ & -2.171 & 0.162 \\
\hline RE & -0.58 & 0.797 & 0.958 & 0.362 \\
\hline CC & -0.66 & $(0.052)^{* * *}$ & 0.127 & $(0.034)^{* *}$ \\
\hline PS & -0.030 & $(0.003)^{* *}$ & -0.413 & $(0.015)^{* *}$ \\
\hline R-squared & \multicolumn{2}{|c|}{0.31} & & 0.72 \\
\hline
\end{tabular}

Source: compiled by authors.

Impact GDP, GNI, UN, Wages, RE have a statistically significant impact at the level of 1-10\% on countries' migration processes for the FMOLS model. Whereas for DOLS, only UN and RE indicators have a statistically significant impact at $1 \%$. The coefficient of determination for both models is more than $30 \%$ and $70 \%$, respectively.

\section{Conclusions}

The country's sustainable socio-political development directly depends on macroeconomic stability, which requires ensuring the growth of macroeconomic indicators. Therefore, there is a need to identify factors that have both direct and indirect impact on macroeconomics. Given the globalization and geopolitical processes, the study of the state of human capital becomes a priority.

According to estimates of several influential world organizations, there is a significant demographic deviation. Most economically developed countries face the problem of nation ageing, while underdeveloped countries face overcrowding in domestic labor markets. Such trends inevitably lead to increased migration sentiment. The growing number of migrants leads to changes in the socio-economic life of the population of the destination country.

Migration is a complex process that leads to the redistribution of the population between countries and entails socio-economic changes. In their research, most scientists confirm the relationship between migration processes and the macroeconomic situation in the country. However, such works' generalised analysis shows a significant variability of such influence from the assessment methodology and the studied macroeconomic indicator. The linguistic determinant plays a vital role in assessing the impact of migration processes. Provided that the donor country and the destination country have a common language, migration frequency increases significantly. A similar situation can be traced to the historical determinant, but colonial ties come to the fore in this case. Such a 
determinant as "freedom of movement" is also often presented in research and is essential for member states of free zone agreements.

Thus, according to the work results, it was found that most of the analyzed scientists use simple estimation models filling them with related indirect migratory factors of influence and macroeconomic indicators, which are formed depending on the primary goal of the work. Therefore, this study allows us to create a list of migration determinants commonly used in typical results to develop an updated methodological framework.

Funding: self-funded.

Author Contributions: conceptualization, Denys Pudryk; methodology, Denys Pudryk; validation, Denys Pudryk; formal analysis, Denys Pudryk; investigation, Denys Pudryk; resources, Denys Pudryk; data curation, Denys Pudryk; writing original draft preparation, Denys Pudryk; writing review and editing, Denys Pudryk; visualization, Denys Pudryk; supervision, Denys Pudryk; project administration, Denys Pudryk.

\section{References}

1. Abbasi-Shavazi, M. J., Hugo (dec.), G., Sadeghi, R., \& Mahmoudian, H. (2015). Immigrant-native fertility differentials: The Afghans in Iran. Asian and Pacific Migration Journal, 24(3), 273-297. DOI:https://doi.org/10.1177/0117196815594718.

2. Alícia Adserà, Mariola Pytliková. The Role of Language in Shaping International Migration. The Economic Journal, 125(586), F49-F81. DOI: https://doi.org/10.1111/ecoj.12231.

3. All the World's Immigration Visualized in 1 Map. (2016). Metrocosm. Retrieved from http://metrocosm.com/global-immigration-map/.

4. Berthou, A., Estrada García, A., Haincourt, S., Kadow, A., Roth, M. A., \& Serve, M. E. D. L. (2019). Assessing the macroeconomic impact of Brexit through trade and migration channels. Documentos ocasionales/Banco de $1911 . \quad$ Available aña https://repositorio.bde.es/bitstream/123456789/8812/1/do1911e.pdf.

5. Bilan, Y., \& Strielkowski, W. (2016). Migration in post-transition economies: immigration surplus in Visegrad group countries. International Journal of Trade and Global Markets, 9(2), 182. DOI: 10.1504/ijtgm.2016.076310.

6. Borjas, G. J. (2019). Immigration and Economic Growth (No. w25836). National Bureau of Economic Research. Available at: https://www.nber.org/papers/w25836.

7. Boubtane, E., Dumont, J.-C., \& Rault, C. (2016). Immigration and economic growth in the OECD countries 1986-2006. Oxford Economic Papers, 68(2), 340-360. DOI: 10.1093/oep/gpw001

8. Bove, V., \& Elia, L. (2017). Migration, Diversity, and Economic Growth. World Development, 89, 227-239. DOI: https://doi.org/10.1016/j.worlddev.2016.08.012.

9. Çağlar Özden, Christopher R. Parsons, Maurice Schiff, Terrie L. Walmsley, Where on Earth is Everybody? The Evolution of Global Bilateral Migration 1960-2000. The World Bank Economic Review, 25(1), 12-56. DOI: https://doi.org/10.1093/wber//hr024.

10. Campos, Rodolfo G. and Timini, Jacopo, An Estimation of the Effects of Brexit on Trade and Migration (May 31, 2019). Banco de Espana Occasional Paper No. 1912 (2019). Available at: http://dx.doi.org/10.2139/ssrn.3396986.

11. Dao, T. H., Docquier, F., Parsons, C., \& Peri, G. (2018). Migration and development: Dissecting the anatomy of the mobility transition. Journal of Development Economics, 132, 88-101. DOI: 10.1016/j.jdeveco.2017.12.003.

12. Database Eurostat. (2019). Eurostat. Available at: https://ec.europa.eu/eurostat/data/database.

13. Docquier, F., Ruyssen, I., \& Schiff, M. W. (2017). International Migration: Pacifier or Trigger for Military Conflicts? The Journal of Development Studies, 54(9), 1657-1679. DOI: https://doi.org/10.1080/00220388.2017.1355456.

14. Dumitrescu, E.I., \& Hurlin, C. (2012). Testing for Granger non-causality in heterogeneous panels. Econ. Model., 29(4), 1450-1460. Available at: https://ideas.repec.org/a/eee/ecmode/v29y2012i4p1450-1460.html. 
15. Durand, J., \& Massey, D. S. (2019). Debacles on the Border: Five Decades of Fact-Free Immigration Policy. The ANNALS of the American Academy of Political and Social Science, 684(1), 6-20. DOI: https://doi.org/10.1177/0002716219857647.

16. G20 Participants. (2020). G20. Available at: https://g20.org/en/about/Pages/Participants.aspx.

17. International migrant stock 2019. (2019). U.N. Population Division Department of Economic and Social Affairs Population. Available at: https://www.un.org/en/development/desa/population/migration/data/estimates2/estimates 19.asp.

18. Kahanec, M., Pytlikova, M., \& Zimmermann, K. F. (2016). The free movement of workers in an enlarged European Union: Institutional underpinnings of economic adjustment. In Labor migration, EU enlargement, and the Great Recession (pp. 1-34). Springer, Berlin, Heidelberg. Available at: https://www.iza.org/publications/dp/8456/the-free-movement-of-workers-in-an-enlarged-european-unioninstitutional-underpinnings-of-economic-adjustment.

19. Key Migration Terms. (2020). International Organization for Migration. Available at: https://www.iom.int/key-migration-terms.

20. Levin, A., Lin, C-F., \& Chu, C-S. J. (2002). Unit root tests in panel data: asymptotic and finite-sample properties. Journal of Econometrics, 108(1), 1-24. DOI: 10.1016/S0304-4076(01)00098-7

21. Lewis, John and Swannell, Matt, The Macroeconomic Determinants of Migration (May 25, 2018). Bank of England Working Paper No. 729. DOI: http://dx.doi.org/10.2139/ssrn.3184893.

22. Luu, Trang Heidi (2019). International Migration and FDI: Can Migrant Networks Foster Investments toward Origin Countries?. Honors Projects. 141. Available at: https://digitalcommons.iwu.edu/econ_honproj/141

23. Manole, S., Pănoiu, L., \& Păunescu, A. (2017). Impact of Migration upon a Receiving Country's Economic Development. Amfiteatru Economic, 19(46), 670-679. Available at: https://www.econstor.eu/handle/10419/169097.

24. Melitz, J., \& Toubal, F. (2014). Native language, spoken language, translation and trade. Journal of International Economics, 93(2), 351-363. DOI: https://doi.org/10.1016/j.jinteco.2014.04.004.

25. OECD's International Migration Database OECD. (2017). Available at: https://www.oecd-ilibrary.org/socialissues-migration-health/data/oecd-international-migration-statistics/international-migration-databaseedition-2017 cceaf10e-en.

26. Rausser, G., Strielkowski, W., Bilan, Y., \& Tsevukh, Y. (2018). Migrant remittances and their impact on the economic development of the Baltic States. Geographica Pannonica, 22(3), 165-175. DOI: https://doi.org/10.5937/gp22-16988.

27. Sondhi, G., \& King, R. (2017). Gendering international student migration: an Indian case-study. Journal of Ethnic and Migration Studies, 43(8), 1308-1324. DOI: https://doi.org/10.1080/1369183X.2017.1300288.

28. Song, C., Shi, S., Chen, J. M., Nijkamp, P., \& Li, X. (2019). The Influence of Emigration on Tourism Outward Foreign Direct Investment: Evidence from China. Journal of Travel Research, 0047287519846430. DOI: https://doi.org/10.1177/0047287519846430

29. Tan, G., \& Hugo, G. (2017). The transnational migration strategies of Chinese and Indian students in Australia. Population, Space and Place, 23(6), e2038. DOI: https://doi.org/10.1002/psp.2038.

30. The model. (2020). NIESR. Available at: https://nimodel.niesr.ac.uk/.

31. Tong, S. Y. (2005). Ethnic Networks in FDI and the Impact of Institutional Development. Review of Development Economics, 9(4), 563-580. DOI: https://doi.org/10.1111/j.1467-9361.2005.00294.x.

32. Vasylieva, T., Lyulyov, O., Bilan, Y., \& Streimikiene, D. (2019). Sustainable economic development and greenhouse gas emissions: The dynamic impact of renewable energy consumption, GDP, and corruption. Energies, 12(17). DOI: 10.3390/en12173289.

33. World Bank (2020). World Government Indicators. Available at http://info.worldbank.org/governance/wgi/index.asp.

34. World Migration $2020 . \quad$ Report (2019). Available at: https://publications.iom.int/system/files/pdf/wmr_2020.pdf.

35. Kharazishvili, Y., Kwilinski, A., Grishnova, O., \& Dzwigol, H. (2020). Social Safety of Society for Developing Countries to Meet Sustainable Development Standards: Indicators, Level, Strategic Benchmarks 
(with Calculations Based on the Case Study of Ukraine). Sustainability, 12(21), 8953. DOI: https://doi.org/10.3390/su12218953.

36. Rui, L., Sineviciene, L., Melnyk, L., Kubatko, O., Karintseva, O., \& Lyulyov, O. (2019). Economic and environmental convergence of transformation economy: The case of China. Problems and Perspectives in Management, 17(3), 233-241. DOI: 10.21511/ppm.17(3).2019.19.

37. Bilan, Y., Pimonenko, T., \& Starchenko, L. (2020). Sustainable business models for innovation and success: Bibliometric analysis. Paper presented at the E3S Web of Conferences, 159. DOI: 10.1051/e3sconf/202015904037.

38. Chygryn, O. (2016). The mechanism of the resource-saving activity at joint stock companies: The theory and implementation features. International Journal of Ecology and Development, 31(3), 42-59. Available at: https://essuir.sumdu.edu.ua/bitstream-download/123456789/80913/1/Vasilyeva_national.pdf.

39. Bozhkova V.V., Ptashchenko O.V., Saher L.Yu., Syhyda L.O. (2018). Transformation of marketing communications tools in the context of globalization. Marketing and Management of Innovations, 1, 73-82. DOI: http://doi.org/10.21272/mmi.2018.1-05.

40. Letunovska N., Lyuolyov O., Pimonenko T., Aleksandrov V. (2021). Environmental management and social marketing: a bibliomentric analysis. E3S Web of Conferences 234. ICIES 2020. DOI: https://doi.org/10.1051/e3sconf/202123400008.

41. Rosokhata, A., Sager, L., (2020). Individual issues of economic security: the study of the impact of changes in migration processes on countries economic and innovative development. Visnyk of Sumy State University, 1, 62-74. DOI: $10.21272 / 1817-9215.2020 .1-07$.

42. Chigrin, O., \& Scherbak A. (2011). Analysis of the main problems of ecologically pure production implementation in Ukraine. Mechanism of economic regulation, 1, 235-241.

43. Ziabina, Ye., Pimonenko, T., \& Starchenko, L. (2020). Energy efficiency of national economy: social, economic and ecological indicators. SocioEconomic Challenges, 4(4), 160-174. DOI: https://doi.org/10.21272/sec.4(4).160-174.2020.

44. Pimonenko, T., \& Lyulyov, O. (2019). Marketing strategies of "green" investments: main provisions and features. Bulletin of Ternopil National Economic University, 1, 177-185. DOI: https://doi.org/10.35774/visnyk2019.01.177.

45. Pimonenko, T., Lyulyov, O., \& Chygryn, O. (2018) Green investment marketing: a mechanism of collaboration between major stakeholders. Bulletin of Azov State Technical University. Economic Sciences Series, 2018, (36). 214-220. Available at: http://eir.pstu.edu/bitstream/handle/123456789/15138/\%D0\%92\%D0\%86\%D0\%A1\%D0\%9D\%D0\%98\%D 0\%9A\%20\%D0\%AD\%D0\%9D\%2036.pdf?sequence=432.

46. Korobets O., \& Kyrychenko K. (2018). State regulation of the social and economic development of the national economy of Ukraine in conditions of the ecological risk escalation. In O. Prokopenko, V. Omelyanenko, Yu. Ossik, (pp. 338-344). National Security \& Innovation Activities: Methodology, Policy and Practice: monograph. Ruda Śląska: Drukarnia i Studio Graficzne Omnidium. Available at: https://essuir.sumdu.edu.ua/bitstream/123456789/67787/1/Propokenko monograf.pdf.

47. Panchenko, V., Harust, Yu., Us, Ya., Korobets, O., \& Pavlyk, V. (2020). Energy-Efficient Innovations: Marketing, Management and Law Supporting. Marketing and Management of Innovations, 1, 256-264. DOI: $\underline{10.21272 / \mathrm{mmi} .2020 .1-21 .}$ 